\title{
SEMPOZYUM DEĞERLENDİRMESİ
}

\author{
I. ULUSLARARASI PROF. DR. FUAT SEZGİN İSLAM BILLIM TARİHİ \\ SEMPOZYUMU* \\ 13-15 Haziran 2019, İstanbul/TÜRKIYE
}

(1) Ziya ŞENa

Cumhurbaşkanlığı himayelerinde, 2019 Prof. Dr. Fuat Sezgin Yılı etkinlikleri kapsamında, Kültür ve Turizm Bakanlığının desteği ile Fatih Sultan Mehmet Vakıf Üniversitesi (FSMVÜ), Prof. Dr. Fuat Sezgin İslam Bilim Tarihi Araştırmaları Vakfı (IBTTAV) ve İstanbul Üniversitesi (IÜ) ortaklı̆̆ında düzenlenen "I. Uluslararası Prof. Dr. Fuat Sezgin İslam Bilim Tarihi Sempozyumu" 13-15 Haziran tarihlerinde İstanbul'da icra edildi. İslam Bilim Tarihi alanında çalışan farklı ülkelerden araştırmacılar, İslam Bilim ve Teknoloji Tarihi üzerine paha biçilemez çalışmalar yapan ve 30 Haziran 2018 'de vefat eden Prof. Dr. Fuat Sezgin'i anmak ve onun ilmi mirasinın izinde, Müslüman bilim insanlarının dünya medeniyetlerine katkılarını konuşmak üzere, İstanbul Üniversitesi'nde gerçekleştirilen sempozyumda bir araya geldiler. İslam bilim tarihi alanında çalışan ve eserler bırakan tarihçilerin davet edildiği ve 12 ülkeden 95 katılımcının yer aldığ 1 sempozyumda açılış ve kapanış konuşmaları hariç 10'u mavi, 10'u da doktora salonunda olmak üzere 20 oturum yapıldı. Bunun 4'ü Perşembe, 8'i Cuma ve 8'i de Cumartesi günü icra edildi. Her oturumda 4 konuşmacı bildiri sundu. Böylece yaklaşık olarak 80'e yakın tebliğ sunulmuş oldu. Geleneksel hale getirilmesi planlanan sempozyumda tebliğler Türkçe, İngilizce ve Arapça olarak sunuldu. Prof. Dr. Fuat Sezgin'in anısına, hem hatırasını

\footnotetext{
${ }^{*}$ Bu çalıșma Manisa Celal Bayar Üniversitesi Bilimsel Araștırma Projeleri Koordinasyon Birimince desteklenmiştir. Proje Numarası: 2019-052.

This work was supported by Scientific Research Project Office of Manisa Celal Bayar University. Project Number: 2019-052

a Doç. Dr., Manisa Celal Bayar Üniversitesi, ziya30@gmail.com
} 
Ziya ŞEN

yaşatmak hem de ortaya koyduğu göz kamaştırıcı ilmî mirasın gelecek nesiller için güçlü bir ilham kaynağı olmasını sağlamak, onu anmak ve anlamak amacıyla hazırlanan sempozyumun açılış programı 13 Haziran Perşembe 09.30'da saygı duruşu, İstiklal Marşı, Prof. Dr. Fuat Sezgin'in hayatının anlatıldığı belgesel, Bilim ve Teknoloji Tarihi sunumu ile başladı. Açılış programında Doç. Dr. Bilen Işıktaş tarafından Ud virtüözü Şerif Muhiddin Targan'a ait Uşşak saz semaisi icra edildi. Sempozyumun açılışına FSMVÜ Rektörü Prof. Dr. M. Fatih Andı, İÜ Rektörü Prof. Dr. Mahmut Ak, İstanbul İl Kültür ve Turizm Müdürü Dr. Coşkun Yılmaz, İBTAV Başkanı Mecit Çetinkaya ile İBTAV Kurucu Başkanı Ethem Sancak, Fuat Sezgin'in eşi Ursula Sezgin, FSMVÜ Bilim Tarihi Bölüm Başkanı Prof. Dr. Mustafa Kaçar ve çok sayıda davetli katıldı.

İBTAV Başkanı Sn. Sancak açılış konuşmalarında; Fuat Sezgin'in ülkesine olan vefası, Gülhane'de yapılan müzenin Sezgin'in çalışmalarının görsel bir kanıtı olduğu, orada inşa edilmekte olan kütüphanenin büyük ölçüde tamamlandığı, bilgiyi üretemeyen toplumların medeniyet inşa edemeyeceği, geçmişi bilmenin önemi, Sezgin'in yarım kalan eserlerinin tamamlanması görevinin bilim adamlarının üzerine bir borç olduğu gibi konular üzerinde durdu. Prof. Dr. Fuat Sezgin'in ömrünü vererek oluşturduğu İslam'ın eşsiz bilim örneklerini Gülhane'de açtıklarını söyleyen Sancak konușmasında “Prof. Dr. Fuat Sezgin'in ömür mahsulü bilimsel eser ve keşiflerini sergilememiz ve aziz naaşını Gülhane'ye defnedişimiz 300 yıllık rövanşın önemli bir başlangıcıdır" dedi.

Me'mun'un ne kadar büyük bir bilgin olduğu konusunda Ethem Sancak şöyle bir anekdot anlattı: "Prof. Dr. Fuat Sezgin hocama bir gün sordum: İnsanlık tarihinin en büyük bilim sever hükümdarı kimdi? Dedi ki: Abbasi Halifesi Me'mun'du. Niçin, diye sordum. Dedi ki: Sarayında, Beytü'l-Hikme'de 300 bilim insanıyla, bizzat kendi de çalışırdı. Bütün hükümdarlar, savaş tazminatı olarak toprak veya altın isterlerdi. Me'mun ise, Tarsus'ta yendiği Bizans kralından tazminat olarak İstanbul'da bulunan 100 cilt yazma eseri istemiști. Yine Ethem Sancak'ın anlatımına göre Prof. Dr. Fuat Sezgin bir defasında şöyle demişti: "Ben Cabir'i tanıyana kadar en büyük bilgin olarak Aristo'yu görürdüm. Ancak Cabir'i tanıyınca gördüm ki Aristo'nun bilgisi Cabir'in dörtte biri kadardır." Sufi lakabı ile tanınan, eğitimini Horasan'da yapan ve Beytü'lHikme'de çalışan Cabir, Horasanlı bir eczacının oğludur. Sağlam bir inanca sahip olan Cabir bir hac dönüşü İmam-ı Ca'fer ile tanışır, yanında 4 yıl kalır ve ondan kelam, hadis gibi dini ilimler tahsil eder.

|470| Açlış konuşmasını İngilizcesi olarak yapan İBTAV mütevelli heyeti üyesi Sn. 
Bilal Erdoğan; Fikirleri geliştirmek için parlak zihinlere ihtiyaç duyulduğunu söyleyerek, bilgi üretmek, düşünmek, derlemek ve toparlamak için çalışan zihinler olması gerektiğini belirtti. Ona göre işte böyle biri olan Fuat Sezgin günde 17 saatini fikir, bilim ve bilgi üreterek geçirirdi. Vakıf olarak amaçlarının, Fuat Sezgin'in çalışmalarını yaygınlaştırmak, yaşamını gençlerimiz için örnek olarak ortaya koymak, Müslümanların Batı'da üretilen bilgiyi almasını, anlamasını ve bunun üzerine eklemeler yapmasını sağlayarak gelecek nesillere bu bilgileri aktarmak olduğunu vurguladı. Toplumların karşılaştığı ekonomik, siyasi ve askeri zorlukların yanında sosyal zorlukların da olduğunu ifade ederek bunların birbirinin parçası olduğunu söyledi ve bu sorunlara çözüm geliştirilmesi gerektiğinin altını çizdi. Batı dünyasının bu noktada ekonomik ve sosyal bir çıkmaza girdiğini ilave etti. Sezgin'in yaşamının dünyanın geleceği için anahtar niteliğinde olduğunu belirttikten sonra günümüzde gençlerin bilime çok fazla ilgi duymadığını, işte bu yüzden yeni fikirlere ve bilime adanmış zihinlere ihtiyaç duyulduğunu, bu yll içerisinde Fuat Sezgin'i tanıtmaya devam edeceklerini ve insanları bilim insanı ve akademisyen olmaya özendireceklerini ifade etti.

İstanbul İl Kültür Turizm Müdürü Dr. Coşkun Yılmaz; Kültür ve Turizm Bakanlığı olarak, İBTAV'ın da katkılarıyla Sezgin'in eserlerinin yer alacağı ve bir ihtisas kütüphanesi olan Fuat Sezgin-Ursula Sezgin Kütüphanesini çok yakında Gülhane'de hizmete açacaklarını söyledi. Atıldığı üniversitede şu an Cumhurbaşkanlığı düzeyinde anılan Sezgin'in vatanına ve milletine küsmemenin en büyük temsilcisi olduğunu anlattıktan sonra kendi tarihini bilmenin ve ilim adamlarına değer vermenin üzerinde durdu.

İÜ Rektörü Prof. Dr. Mahmut Ak, Sezgin'in hayatını anlatarak başladığı konuşmasında hocanın doktora tezinin Mecazu'l-Kur'an, doçentlik tezinin ise Buhari'nin Kaynakları olduğunu söyledi. Sempozyumun gerçekleşmesinde katkısı olanlara teşekkür etti.

Daha sonra İÜ Rektörü Prof. Dr. Mahmut Ak ile FSMVÜ Rektörü Prof. Dr. M. Fatih Andı, Fuat Sezgin'in eşi Ursula Sezgin'e çiçek takdim etti.

Açılış konuşmalarının akabinde verilen öğle arası sonrasında sempozyum kapsaminda; 'Fuat Sezgin'le İslam Bilim ve Teknoloji Tarihi Sergisi' ile 'Fuat Sezgin Anısına: Bilimden Sanata Yansımalar Sergisi' ziyarete açıldı ve öğleden sonraki oturumlara geçildi.

Sempozyum kapsamında aslında açılış konferansını yapacak olan TC. Cumhurbaşkanı Başdanışmanı ve Sözcüsü Sayın Doç. Dr. İbrahim Kalın, bir gün sonraki cumartesi oturumunda "Bilim, Teknik, Tefekkür: Fuat Sezgin'le Evrendeki İşaretleri Okumak" başlıklı bir konuşma yaptı. Sn. Kalın, Sezgin'in 
Türkiye'de ve dünyada anılması ve eserlerinin daha geniş kitlelere ulaştırılması için önemli faaliyetler yapılmasından duyduğu memnuniyeti dile getirdi. Sezgin'in sadece İslam bilim tarihi çerçevesinde değerlendirilemeyecek kadar önemli çalışmalara imza atan ilim adamı ve düşünür olduğunu söyledi. Geçmişte olduğu gibi günümüzde de medeniyetimizin kültürünün aktarılmasının öneminden bahsetti. Herhangi bir eğitim kitabında bilim, felsefe ya da medeniyetler tarihi bölümünde aklın, bilimin, felsefenin, mantığın ve genel manada medeniyetin bugünkü Yunan adaları civarında başladığını, bunun daha sonra aynı istikamette devam ettiğinin görüldüğünü anlattı. Eflatun'un Mısır'a ve Mezopotamya'ya atıflar yaptığını söyledi. Avrupa merkezli tarih perspektifinin büyük oranda bilimi, düşünceyi, Avrupa tarihinin bir noktasına sabitlediğini ve bir coğrafyayla sınırlandırdığını belirttikten sonra Avrupa merkezci tarih anlayışının bilimden düşünceye, sanattan felsefeye her alanda ana paradigmayı belirleyen bir bakış açısı olmaya devam ettiğini kaydetti. Sezgin'in eserlerinin en önemli mesajının, Avrupa merkezli tarih perspektifini sorgulayan, bunun sınırlarını zorlayan yeni bir tarih anlayışının ortaya konulması olduğunu belirterek, "kendisinin de daha 1940-1950'li yıllardan itibaren tespit ettiği, sonraki yıllarda da aşmak için gayret sarf ettiği bu temel sorun bugün de hala bizim bilim tarihine, düşünce tarihine, medeniyet tarihine bakışımızı belirlemeye devam ediyor." dedi. Daha sonra Sn. Kalın konuşmasında genel anlamda şu hususlar üzerinde durdu: Sezgin, Batılıların karanlık çağ dediği Orta Çă̆'ın İslâm medeniyetinin aydınlanma çağı olduğunu söylerdi. Bilim tarihi alanındaki çalışmalarına bakıldığında o, unutturulan bir tarihi bize hatırlatan büyük bir bilim insanı ve mütefekkirdir. Sezgin'e kadar İslam Bilim Tarihi genel bilim tarihinde küçük bir dipnot iken bir anda onun çalışmalarıyla dünya bilim tarihinin merkezine oturarak tarihi birikim haline gelebildi. Sezgin İslam bilim tarihinin özgün olmadığı iddiasının, 8-9. yüzyıldan 17. yüzyıla kadar devam eden büyük bilimsel faaliyetler içerisinde temelsiz bir tez olduğunu birçok eserinde ortaya koydu. Gazali ve İbn Sina'yı besleyen kültürel ortam ve iklimin yeniden inşa edilmesi, bütün boyutlarıyla anlaşılması, medeniyet tartışmaları açısından büyük önem arz eder. Fuat Sezgin'in çalışmaları kültürel iklimi ortaya koyması açısından bilim adamlarının nasıl yetiştiğine dair ipucu sunar. Kalın, Sezgin'in tarihlendirme ya da dönemlendirme meselesi üzerinde durduğunu belirterek konuşmalarına şöyle devam etti: "Hala kendimize ait bir tarihlendirme ve dönemlendirme faaliyeti ortaya koymuş değiliz. Son dönemde bunun en önemli istisnası olarak İslam Düşünce Atlası başlı̆̆ altında birkaç ilahiyatçı arkadaşımızın ortaya koyduğu bir çalışma 
yayımlandı. $\mathrm{Bu}$, kendimize ait bir tarihsel dönemlendirme yapabilme açısından önemli bir çalışma. Bu bir kitapla, birkaç ilim adamının çabasıyla olabilecek şey değil. Aydınlanma Çağı, Karanlık Çă̆, Orta Çağ gibi terimler zihinlerimize o kadar köklü bir şekilde yerleşti ki, bunları aşmak için yepyeni bir tarih okumasına ihtiyacımız var. Fuat Sezgin hoca, Batılıların karanlık çağ dediği dönemler aslında İslam medeniyetinin aydınlık çağlarıdır, diyordu." Konuşmacı Osmanlı tarihinin dönemlendirilmesi konusunda da henüz zihni berraklığa kavuşulmadığını söyledikten sonra siyasi ve askeri süreçlere göre 18-19. yüzyılın sıkıntılı bir dönem olduğunu ancak sanat tarihi açısından bu yüzyılların Türk musikisi, hat ve ebru sanatının zirve yaptığı dönemler olduğunu anlattı. Sn. Kalın son olarak, Sezgin'in mirasının hatırlanmasının ve açtığı yolda bilim tarihi çalışmalarının derinleștirilmesinin önemli olduğunu belirterek şöyle dedi: "Kendisi 300 bine yakın el yazmasını hayatı boyunca elden geçirmiş bir ilim adamı olarak, yapılması gerekenin ancak yüzde birini yapabildiğine inanıyordu. Bu dünyadan giderken bize çok önemli görevi bıraktı. 60 küsur yıllık ilim hayatına sığdırdığı büyük eserler aslında yeni çalışmaların zeminini oluşturuyor. Bu da bizim bu mirası yaşatmamız ve yarınlara taşımamız için hem bireysel hem de kurumsal olarak bu faaliyetleri desteklememiz, yolu büyütmemiz büyük önem arz ediyor. Eserlerinin bugünün ve yarının nesillerine yol göstereceğine inanıyorum."

İslam bilim tarihinin yeniden uyanışını ve çalışmaların hız kazanmasını sağlayacak olan sempozyumda eş zamanlı oturumlar yapıldı. Aynı anda birden fazla oturum esasıyla gerçekleştirilen tüm sempozyumlar gibi bu sempozyum da bizlere her tercihin aynı zamanda bir vazgeçiş barındırdığını hatırlattı. Dolayısıyla iki salonda eşzamanlı olarak devam eden sempozyumda bir oturumu tercih ettiğinizde diğerinden vazgeçmiş oluyorsunuz. (Ancak biz sempozyumun takip edemediğimiz oturumları konusunda I. Uluslararası Prof. Dr. Fuat Sezgin İslam Bilim Tarihi Sempozyumu, 13-15 Haziran 2019 Bildiri Özetleri kitapçığından istifade etmeye çalıştık.) Toplantıda çok fazla tebliğ sunulması ve yukarıda da söylenildiği üzere sempozyumun aynı anda iki solanda icra edilmesi sebebiyle maalesef bizim tüm oturumları takip etme imkânımız olmadı. İşte bu gibi sebeplerden dolayı biz bundan sonraki kısımda sempozyuma katılan tebliğcilerin isimleri, unvanları, tebliğ başlıkları ve tek tek neler anlattıkları gibi hususlar üzerinde durmaktan ziyade sunulan tebliğlerde ele alınan konulara genel olarak temas etmek istiyoruz:

Prof. Dr. Fuat Sezgin'in üniversitedeki düşmanları hocayı karalayıp üniversiteden attırmışlar. Sezgin, 20 sene zindanda kalan bir alimin orada pek çok eser yazdığını, kendisinin özgür halde iken yazmamasının büyük bir 
eksiklik olduğunu düşünürdü. Kitapları yavaş ama çok derinden okurdu. Çalışmalarından kendi sağlığına çok fazla dikkat etmezdi. Hasta olduğu zaman genelde ayakta tedavi görürdü. Defalarca teklif edilmesine rağmen, bu büyük işler bir Alman tarafından yapıldı denmemesi için Sezgin, Alman vatandaşlığını kabul etmemişti. Fakat bu başarılardan Türkiye'nin haberdar olmaması da onu derinden üzmüştü.

Sezgin'e göre; Batı dünyası ilmi Müslümanlardan alıp ileriye doğru götürdü. Rönesans birkaç kişinin uydurması idi. Batı medeniyetinin temeli İslam kültür ve bilimine dayanıyordu. Bizler Batıyı yabancı olarak görmemeliyiz ve onlardan istifade etmeliyiz.

Sezgin GAS ile Arap İslam kültür dünyasının bilimler tarihindeki önemli katkısını gösterdi ve onu dünya tarihinde layık olduğu yere koydu. Eserin muhtevasının İslam âleminde bir yeniden diriliş ve kalkış uyandıracağına inanıyordu ki bu bütün çalışmalarının gayesiydi. Bu gayeye ulaşmak için sadece analitik düşünce kabiliyetine sahip bir zekâ yetmezdi. Her şeyden önce, Allah'a iman ve tevekküle dayanan bir iç kuvveti lazımdı. Bu manevi kuvvet, ona ömrünün sonuna kadar, tatil günleri de dahil her gün çalışmak için gerekli sebat ve mukavemet gücünü veriyordu. Çalışmayı ibadet olarak gören ve bu yüzden her anını ibadetle geçiren Sezgin her zaman gayet mütevazı, zahidane denebilecek bir hayatı tercih etti. Yaptığı işi ilahî bir vazife olarak kabul ediyordu. Hayatının her anı için Allah'a hesap verme şuuru ve duygusu ile yaşıyordu. Bu sebeple şahsını ve ihtiyaçlarını her zaman arka plana almayı şiar edinmişti. İşte bundan dolayı hocanın yaptıklarını ve eserlerini değerlendirirken bunların zemininde yatan maneviyatı ve hayat felsefesini anlamak ve görmek gerekir.

Sezgin'in ana hedeflerinden birisi, henüz el yazması formunda olan ve ulaşılmayı ve gün yüzüne çıkmayı bekleyen kaynak eserleri bilim dünyasına kazandırmaktı. Brockelmann'ın bu konudaki kaynak eserini (GAL) zenginleștirerek yeniden yazma kararı 1954'te netleştikten sonra Sezgin, bu gaye ile İstanbul kütüphanelerinde bu eserleri araştırmaya başlamıştı. Sezgin'in 1942'de İstanbul Üniversitesi'nde karşılaştığı hocası Hellmut Ritter, onun ilgisini bilimler tarihine döndürmüştü. Sezgin'in, bir protestan rahibinin oğlu olarak doğmuş, fakat İslam bilimlerine yöneldikten sonra İslam âlimlerinin ve mutasavvıfların metinleri vasıtasıyla tanıştığı şahsiyetlerin dinî, fikrî ve estetik âleminde derinleşmiş, onları zevk edinmiş bir büyük âlim olan Ritter'den öğrendikleri ona heyecan veriyordu. Sezgin maddî olarak çok zor şartlarda okumasına rağmen bu ilim zevkinin ve bunu |474| kendisine sunan böyle bir hocaya sahip olmanın, bütün zorlukları 
unutturduğunu ifade eder. Alman ekolü içinde yetişen Hellmut Ritter, dünya şarkiyat geleneğinde önemli bir yere sahipti ve el yazması kaynaklara nadir rastlanan derecede hâkimdi. Ritter ile Sezgin arasında usta çırak ilişkisine dair pek hatıra vardl.

Sezgin'e ait Buhârî̀nin Kaynakları, İlahiyat alanında Türkiye'deki erken dönem akademik çalışmalardan birisidir. Eserde, Buhârî'nin Sahîh'indeki "Kitâbü't-Tefsîr" bölümü ele alınmıș ve tefsir tarihi konusuna ağırlık verilmiştir. Bu çalışması ile tefsirin hadisin bir bölümü olmayıp müstakil olarak geliştiğini ispat eden Sezgin, söz konusu eserinde, Buhârî'nin Sahîh'inin tefsir bölümündeki dil izahlarına yer vermiş, söz konusu bölümü "Buhârînin Kur'an Tefsiri" adı altında ele aldığını beyan etmiștir. Sezgin, Buhârî̀nin Sahîh'inin tefsir bölümünü Alî b. Ebî Talha'ya nispet edilen sahifelerden almış olmasının ihtimal dâhilinde olduğunu belirtmiştir.

Ebû Bekir er-Râzînin altı bölümden oluşan "Kitâbu'l-hâvî fi't-tıb" adlı eserinin IX. bölümü rahim hastalıkları ile ilgilidir. Eserde Yunanca, Bizans, Süryani ve Hint kaynakları kullanılmıştır. Razî’nin tıp ilmine dair bu eserinin Amerika ve Avrupa kütüphanelerinde pek çok yazmaları vardır. Bu eser üzerine çalışmalar 18. sonunda başlamış ve bütün ayrıntılarıyla çalışılmıştır. Razî’nin tıpla ilgili kitapları 16. Yüzyıldan sonra Avrupa'da yüksek fiyatlara satılmıştır.

Batı, göz tıbbında Müslümanlara çok şey borçludur. İbn Sînâ'nın tıp ve özellikle de göz hastalıkları ve felsefe alanlarında muazzam katkıları vardır. Son zamanlara kadar gözün nesneyi gördüğüne inanılırdı, ama şimdi ışığın nesneden bize yansıttıklarını gördüğümüzü keşfettik ki İbn Sina bunu bin sene önce yazmıştı. Ayrıca İbn Sina renk farklarına kadar kataraktla ilgili bugün bilinen bütün bilgileri yazmıștır. Bugün gözün beș tabakası olduğu bilinmekte ve bu ancak elektronik mikroskopla bulunmuştur. İbn Sina ise o gün için gözün dört tabakasını tek tek yazmış, beşinciyi bulmak için elektronik mikroskop gerekli olduğundan bunu yazamamıştır. İbn Sina, Aristo ve Galen'i birleştirmiştir. Aristo ve Galen' in dediğine göre aklın mekânı beyin değil, kalptir. 0 dönemde, mizaçtan kaynaklanan hastalıklar da araştırılmış ve bunun haklılığı ortaya konulmuştur. Kanser tipi hastalıklarla ilgili tedaviler de geliştiren İbn Sina, kanserin temel olarak dört mizah dengesini (kan, balgam, sarı safra ve kara safra) bozacak siyah safranın fazlalığına neden olduğuna inanıyordu. Yani kanser hastalarında aşırı safra salgılanması olurdu. Yer merkezli evren modelinde yerin hareketsizliğine dair İbn Sînâ'nın önemli değerlendirmeleri ve bu değerlendirmelerin İbn Sînâcı bir metin olan Hikmetü'l-'ayn'da önemli yansımaları vardır. 
Farsça konuşabilen Prof. Fuat Sezgin, İranlı alimler tarafından 11. yüzylla kadar yazılan Arapça metinlerle geniş bir şekilde ilgilendi. Onun eserlerinden bazıları Farsçaya çevrildi. O, Arapça el yazmaları hakkında bilgi toplamak için İran'a gitti. Birkaç yıl sonra da, İslam medeniyetinin bilimsel ve kültürel mirasının incelenmesine yaptığı büyük katkılardan dolayı ödül almaya İran’a geldi.

Fuat Sezgin'in İslam bilim tarihi yazıcllığına önemli katkıları vardır. İslam bilimlerinin gelişiminde siyasi, sosyal, ekonomik ve çevresel faktörler yer alır. İslam bilimlerinin farklı medeniyetlerin bilimsel birikimlerine katkısı oldukça fazladır. İslam medeniyetinde geliştirilen bilimsel aletler ve teknoloji ürünlerinin önemli bir yeri vardır.

Ali Kuşçu'nun hesaplamalarda kullandığı bazı matematiksel yöntemler ve eserlerindeki matematiksel yöntemlerin bilim dünyasındaki etkileri çok önemlidir.

Bîrûnî, dünyanın gelmiş geçmiş en büyük âlimlerinden biridir. Âlim, bilim dalları arasında geçiş yapabilen kişidir. Matematik ve fizikten astronomiye; jeoloji ve mineralojiden coğrafyaya; sosyal antropoloji ve dinden tarihe kadar pek çok ilmi alanda eserler veren Bîrûnî, şeref timsali büyük bir bilge insandır. Tevazu sahibi olup, eğilmesini bilen ve eserlerinde sıkça başarı Allah'tandır vurgusu yapan Bîrûnî, elmas ve yakuttan amatiste; malakit ve mıknatıstan cama kadar 31 ayrı taşı, bugün de geçerli olan mineraloji bilimi ilkeleri ile açıklamıştır. Kendi geliştirdiği ölçü aletleri ve mekanizmalarda çok başarılı olan Bîrûnî'nin günümüze ulaşmış bulunan önemli eserleri arasında bilimin kronolojik gelişimini irdeleyen el-Âsâru'l-bâkiye, matematiksel coğrafyanın temellerini veren Tahdîdü nihâyâti'l-emâkin, döneminin matematiksel bilimlerini ve astrolojik temelleri 570 soruda özetleyen etTefhîm fî evâili sınâ'ati't-tencîm, bir bilim ve bilgiler ansiklopedisi niteliğindeki el-Kânûnu'l-Mes'ûdî, güneş saatlerinin kuramsal temellerini veren Ifrâdü'l-makâl fí emri'l-ezlâl (zılâl) ve usturlapların yapım ve kullanımını konu edinen Kitâb fi'stî́âbi'l-vücûhi'l-mümkine fi san'ati'lasturlâb kitapları sayılabilir.

Mehmed Said Efendi'nin kendisinin icat ettiğini söylediği Müsellesiye adlı mühendislik aleti üzerine olan risalesi ile Avrupa kaynaklarından tercüme ederek hazırladığı Pergâr-ı Nisbe aletini anlattığı risalesi onun bilimsel aletlere olan ilgisini göstermektedir. Ayrıca onun 1154/1741 senesinde elHacc Ahmed Paşa için hazırladığı ve arazi ölçümünde (misâha) kullanılan tabla adı verilen bir aletten bahsettiği risalesi, Ebu Sehl Nu'mân Efendi'nin tabla aletini anlattığı Tebyînü a'mâli'l-misâha adlı eseriyle aynı dönemde 
yazılmıştır.

Jules Janssens'in Makâsıd ile Tehâfüt arasında herhangi bir bağlantının olmadığını ve Gazali'ye ait olan bu kitabın asıl başlığının Makâsıdu'l-felâsife olmadığını iddia ettiği ileri sürüldü.

İlhanlılar (1256-1357) devrinde şarkın ilim ve kültür merkezi durumuna gelen Azerbaycan'da dört büyük eğitim ocağından (diğerleri Kazaniye, Reşidiye ve Sultaniye medreseleridir) biri olan ve Ortaçağ İslam uygarlığının en büyük bilim kurumu olarak değerlendirilen Merağa Rasathanesi 12591271 yıllarında yapılmıştır. 16 binadan oluşan bu külliyede Halep, Bağdat, Şam, Kahire ve diğer bölgelerden getirilen 400 bin eserin bulunduğu kütüphane mevcuttur. Merağa Rasathanesi bir araştırma merkezi olmanın yanında yükseköğretim hizmeti sunan bir eğitim ocağı olarak da çalışmalarını sürdürmüştür. Yaklaşık 50 seneden fazla faaliyet gösteren bu Rasathane'de yapılan bilimsel çalışmalardan daha sonraları Çin'de, Semerkant'ta, Hindistan'da, İstanbul'da ve dört asır boyunca Avrupa'da geniş çapta faydalanmışlardır.

İslam uygarlı̆̆ı için müzik yalnızca icra pratiğiyle değil, teorik zenginliğiyle de yazılı literatürün bir parçasını oluşturmuştur. Müzik, Emevi ve Abbasi saraylarından başlayarak bütün İslam devletlerinde gündelik hayatın estetik formlarından biri haline dönüşmüștür. Prof. Dr. Fuat Sezgin, müzik tarihi literatürüyle de ilgilenmiş, Arap-İslam mûsikî tarihine yönelik katkı sağlayıcı yayınlar hazırlamış ve birçok önemli eserin neşrine imkân sağlamıştır. Bunun yanı sıra enstitünün müzesinde mûsikî aletlerinden oluşan bir sergi oluşturmuştur.

Endülüs, İslam medeniyetinin batı ucunda önemli bir bilim merkezi olarak öne çıkmıştır. Sezgin, çalışmalarında önemli bir yer tutan Endülüs'te gelişen İslam Bilim Tarihi eserlerinin taşıdıkları önemi bihakkın takdir etmiştir. İyi bir bilgin olan İbn Sîd el-Batalyevsî; astronomi bilgini ez-Zerkâlî; Endülüs'te gelişen felsefî düşüncenin başlıca temsilcileri olan İbn Bâcce, İbn Tufeyl, İbn Rüşd ve İbn Seb'în gibi kişi merkezli eserlerinin yanı sıra, tarihî coğrafya ve İslam felsefesinin Batı'ya aktarımı gibi çalışmalarını sadece Endülüs'e ayırmıştır.

13. asırda Anadolu topraklarının büyük oranda Türkleşmesinin ve İslamlaşmasının ardından Anadolu'da matematik kitapları üretilmeye ve bu kitaplar aracılığıyla eğitim-öğretim faaliyetleri yürütülmeye başlanmıştır. Anadolu'da üretilen ve günümüze ulaşabilen matematik kitaplarından en erken tarihlisi, Emînüddin Ebherînnin (ö. 733/1333) Arapça olarak 14. yüzyılın ilk çeyreğinde telif ettiği Fusûl kâfiye fî hisâbi't-taht ve'l-mîl adlı 
Ziya ŞEN

eserdir. Eserin ondalık konumsal sayı sistemi ile bu sisteme göre yapılan tüm hesap işlemlerinin Anadolu coğrafyasında tanınması, yaygınlaştırılması ve zamanla değişen ihtiyaçlara uygun olarak yeniden üretilebilmesi için başlangıç noktasını temsil ettiği söylenebilir.

Taşınabilir astronomi aleti olan dâ'ire-i mu'addil hakkında az sayıda risale hazırlanmıştır. Bunun yapısı, kullanımı ve Osmanlı astronomi aletleri tarihindeki yerini konu alan pek fazla araştırmayla da karşılaşılmamıştır. Bunu konu alan iki eser ön plana çıkmıştır. Bunlardan ilki Mustafa b. Ali elMuvakkit'in (ö. 1571) dâ'ire-i mu'addil üzerine risalesidir. İkincisi ise denizci Seydi Ali Reis'in (ö. 1563) beş taşınabilir astronomi aletinin yapısı ve kullanımını anlattığı Mir'ât-ı Kâ'inât isimli eserinde yer alan dâ'ire-i mu'addil bölümüdür.

Kitâbu'l-Ahcâr (Taşlar Kitabı) Aristoteles'e atfedilir. Günümüze 8. veya 9. yüzyılda yapılan Arapça çevirisiyle ulaşmıștır. İslam bilim tarihinde mineraloji alanında kaleme alınmış olan bu çalışma, değerli taşlar, metaller ve bazı kimyasal maddelerin dönemin bilgi ve yorum kapasitesi çerçevesinde mineraloji, simya/kimya, tıp ve metalürji gibi hemen hemen her yönden ele alındığı bir eserdir. İçeriğindeki malzemenin Geç Antikçağ'dan geldiği Kitâbu'l-Ahcâr'ı Arapçaya çeviren kişi olarak gösterilen ismin tarihte gerçekten yaşamış biri olduğuna dair herhangi bir bilgiye sahip değiliz. $\mathrm{Bu}$ nedenlerle Kitâbu'l-Ahcâr, bilim tarihi açısından oldukça tartışmalı ve problematik bir metindir. Bununla ilgili tartışmalar, eserin gerçekten kaynak bir metinden mi çevrildiği yoksa Arapçada mı üretildiği noktasında seyretmiştir.

Sezgin'e göre Yâkût al-Hamevî ve İslam dünyasında yetişen yüzlerce âlim antik Yunan'daki coğrafya düzeyi ile 16. yüzyllda bir anda Avrupa'da ortaya çıkan coğrafya biliminin gelişim düzeyi arasındaki farkı anlayabilmek açısından kilit önemdedir. Onun Mu'cemu'l-büldân adlı eseri, Batı dışı dünyadaki coğrafyanın gelişmişlik düzeyini göstermesi açısından önemlidir. 13. yy'ın ilk çeyreğinde kaleme alınan yaklaşık 4.000 sayfalık bu coğrafya sözlüğü gerek seleflerinin günümüzde kayıp olan eserlerinden yaptığı alıntılarla gerekse de meseleleri ele alışındaki ihtimamı ile üzerinde durulmayı hak etmektedir. Eser, meydana geldiği kültür çevresinde coğrafya biliminin ulaştığı seviyeyi göstermesi açısından da önemlidir.

Takvîmü'l- büldân'da her șehri hakiki iklim üzerinden değerlendiren Ebü'lFidâ, bu hususta kendinden sonraki coğrafyacıları da etkilemiştir. Osmanlı coğrafyacıları da bu metot üzerinden kendi eserlerini kaleme almışlardır. Âşık Mehmed, Mehmed Suûdî, Sipâhîzâde Mehmed, Kâtib Çelebi ve Evliya 
Çelebi gibi Osmanlı coğrafyacıları yeryüzünü ve şehirleri hakiki iklim üzerinden ayrıştırmakta ve tanımlamaktadır.

Abbasi dönemindeki çeviri hareketi, Bizans İmparatorluğu'ndaki Makedonya Rönesans'ına ilham vermiştir. Hem Bizans imparatorları hem de Abbasi halifeleri âlimlerini yoğun bir şekilde destekleyip bilimi bir uluslararası propaganda aracı olarak kullanmışlardır.

Cerrahi alet çizimlerinin yer aldığı Kitâbü't-Tasrîf nüshaları Türkiye'de el yazması kütüphanelerinde mevcuttur. Osmanlı hekimbaşılarının incelediği ve Topkapı Sarayı hazinesinde bulunan tıp yazmaları arasında Zehrâvî̀nin Kitâbü't-Tasrîf $\mathrm{i}$ önemlidir.

Literatürde Osmanlılarda Uranüs ve Neptün gezegenlerinden bahseden ilk çalışmanın Abdullah Şükri el-Konevî̀nin 1857'den sonraki bir tarihte yazdığı Tenkîhu'l-eşkâl alâ tavzîhi'l-idrâk adlı eseri olduğundan söz edilir. Ancak söz konusu değerlendirme Neptün açısından şimdilik doğru olmakla beraber, Uranüs için doğru değildir. Uranüs'ten bahseden ilk çalışma, Kuyucaklı Mehmed Âtıf'ın 1831'de kaleme aldığı Teshîlü'l-idrâk terceme-i teşrîhi'l-eflâk adlı eseridir. Bu eserlerin her ikisi de medrese çevreleri için yazılmıştır.

Matematik yazıları uluslararası matematik dergilerinde yayınlanan ilk Türk matematikçisi olarak kabul edilen ve sayılar teorisi alanına orijinal katkılar sağlayan Mehmet Nadir, Osmanlı'nın son, Cumhuriyet'in ilk dönemlerine denk gelen 1856-1927 yılları arasında yaşamış önemli bir matematikçimizdir. Matematik, eğitim, edebiyat, siyaset gibi farklı konular hakkında gazete ve dergilerde pek çok yazı yazmıştır. Matematik çalışmalarının hemen hemen tamamı sayılar teorisi üzerinedir. "Tamam-ı adedî” usulünün bölme işlemine uygulanması ilk defa Mehmet Nadir tarafından yapılmıştır. Nadir'in matematik alanındaki çalışmaları; İstanbul Darülfünun Fen Fakültesi Mecmuası'nda yayınlanan makaleleri, Hesâb-ı Nazarî adlı kitabı ve uluslararası dergilerde yayınlanan soru ve cevapları olmak üzere üç başlık altında sıralanabilir.

Yazma eser temelde kitap ve nüsha olarak iki kısımdan oluşur: a. Kitap: Müellif tarafından telifi sona erdirilen şeydir. Telife büründügü ilk haldeki yalınlıktadır. Müellifler, yazmanın "el-kitab" tarafını oluştururlar. b. Nüsha: Kitabın dolaşıma giren halleridir. Her müdahaleden sonra tekrar eden, tekrar ettikçe büyüyen, büyüdükçe kemmiyet ve keyfiyet açısından çoğalan bir kar tanesi gibidir. Her bir nüsha neredeyse müstakil bir teliftir ve her bir nüshaya müstakil bir isim verilse belki de yeridir. Nüshalarının yazarları müstensihler ve okurlardır. Mütalaa edilmek, okunmak, okutulmak, satılmak için ya da başka sebeplerle çoğaltılan, elden ele dolaşan, vakfedilen, satın alınan, 
notlarla kümülatif bir bilgi vasıtası haline gelen şey, nüshadır. Nüshalar sivil hayata eşlik eder; okurun rahlesinde, elinde, ders ya da müzakere meclisinde, mütalaa esnasında, yolculuğunda çeşitli hallerine tanıklık eder, notlarına ev sahipliği yapar. Bu tanıklıklar arttıkça nüsha anlam kazanır, hatta kimi zaman nüshanın kıymeti kitabın önüne geçer. Kitap bir ruh, nüshaların her biri ise bu ruhu da mündemiç bir bedendir ve kitap kimliğe bürünen her bir nüshada yeniden canlanmaktadır.

Ortaçağ İslam dünyasında astronomi çalışmaları, Antik Yunan astronomisinden etkilenmiştir. Aristoteles'in kozmoloji belirlemeleri ve Batlamyus'un matematiksel astronomisi Ortaçağ astronomisinin temelini oluşturur. Aristoteles'in fiziksel ve Batlamyus'un matematiksel yapısını kurguladığı bu göksel şema İslam astronomları tarafından da kabul edilmiş, çevirilerle Antik Yunan'ın astronomi çalışmaları İslam uygarlığına geçmiştir. 9. yy.'dan itibaren İslâm astronomları önemli katkılar yapmışlar, astronomide yeni teknikler geliştirmişler ve gözlemevlerinin kuruluşunda öncü rol oynamışlardır.

15 Haziran 2019 tarihinde İÜ Rektörlük Binası Doktora Salonu'nda yapılan sempozyumun kapanış oturumunda IÜ Rektörü Prof. Dr. Mahmut Ak, Fatih Sultan Mehmet Vakıf Üniversitesi Rektörü Prof. Dr. M. Fatih Andı, Fatih Sultan Mehmet Vakıf Üniversitesi Rektör Yardımcısı Prof. Dr. Fahameddin Başar ve Prof. Dr. Fuat Sezgin İslam Bilim Tarihi Araştırmaları Vakfı Başkanı Mecit Çetinkaya birer konuşma yaptılar. Bu oturumda Prof. Dr. Fuat Sezgin İslam Bilim Tarihi Araştırmaları Vakfı adına çok yararlı bir sempozyum gerçekleştiği ve bu yılın en anlamlı faaliyetlerinden birisinin bu sempozyum olduğu üzerinde duruldu ve organizasyona ev sahipliği yapan İstanbul Üniversitesi'ne ve sempozyum katılımcılarına teşekkür edildi. Uygarlıkların sosyal hayatın pek çok alanında kendisini gösterdikleri, ekonomi, siyaset ve askeri ilişkiler gibi birçok sütun üzerinde yükseldikleri, ancak bunlar içerisinde düşünce, sanat ve bilim sütunlarının ön plana çıtığı ve eğer bir uygarlık kendisini bu üç alanda öne çıkarmışsa veya emsali ile boy ölçüşecek şekilde inşa etmişse, o uygarlığın geleceğe doğru önemli adımlar atmış anlamına gelebileceği ifade edildi. İslam medeniyetinde İslam düşüncesi, İslam sanatı ve İslam biliminin öne çıktı̆̆ı , bu alanlarda yapılan çalışmaların çok önemli olduğu, bu üç alanın öz güven verdiği ve aidiyet duygumuzu kaybetmememizi sağladığı, işte Sezgin'in misyonunun da bu olduğu ve onun İslam düşünce, bilim ve tarihi alanında öneminin burada kendisini gösterdiği üzerinde duruldu. İslam bilim tarihinin, dünyadaki medeni ve kültürel hareketlerin oluşmasında temel teşkil eden fikirlerin bütünü, manzumesi ve kaynaklarının temeli olduğu anlatıldı. 
Sonuç olarak İslam medeniyeti tarihinin başlangıcından itibaren gelişmiş naklî ve aklî bilimlere ait literatürü konu edinen (GAS) adlı eseri başta olmak üzere ortaya koyduğu paha biçilmez çalışmalarla Prof. Dr. Fuat Sezgin, İslam bilimleri tarihindeki pek çok yaygın kabulü değiştirecek sonuçlara ulaşarak geriye önemli bir ilmî miras bırakmıştır. Toplantıya ağırlıklı olarak katılım sağlayan yabancı bilim adamlarının, Müslüman bilim insanlarının eserleri üzerine değerlendirmeler yaptığı bu sempozyumda, onların Arapça eserleri en ince ayrıntısına kadar inceledikleri dikkatlerden kaçmamıştır. I. Uluslararası Prof. Dr. Fuat Sezgin İslam Bilim Tarihi Sempozyumu, ilmi bakımdan oldukça doyurucu olmuş, organizasyon oldukça başarılı bulunmuştur. Sempozyumun açılış konuşmalarının, sunulan tebliğlerin, müzakerelerin ve değerlendirme konuşmalarının bir kitap halinde neşredilmesini temenni ediyor ve bu önemli sempozyuma katkı sağlayan ve emeği geçen herkese teşekkür ederek sempozyumla ilgili değerlendirmelerimizi burada tamamlamak istiyoruz.

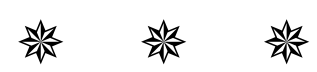

